\title{
Revisiting fertilisers and fertilisation strategies for improved nutrient uptake by plants
}

\author{
Prem S. Bindraban ${ }^{1}$ - Christian Dimkpa ${ }^{1}$ - Latha Nagarajan ${ }^{2} \cdot$ Amit Roy $^{2}$. \\ Rudy Rabbinge ${ }^{3}$
}

Received: 4 February 2015 /Revised: 19 May 2015 / Accepted: 6 July 2015 / Published online: 16 July 2015

(C) The Author(s) 2015. This article is published with open access at Springerlink.com

\begin{abstract}
Meeting human needs within the ecological limits of our planet calls for continuous reflection on, and redesigning of, agricultural technologies and practices. Such technologies include fertilisers, the discovery and use of which have been one of the key factors for increasing crop yield, agricultural productivity and food security. Fertiliser use comes, however, at an environmental cost, and fertilisers have also not been a very economically effective production factor to lift many poor farmers out of poverty, especially in African countries where application on poor soils of unbalanced compositions of nutrients in fertilisers has shown limited impact on yield increase. Agronomic practices to apply existing mineral fertilisers, primarily containing $\mathrm{N}, \mathrm{P}$ and $\mathrm{K}$, at the right time, the right place, in the right amount, and of the right composition can improve the use efficiency of fertilisers. However, the overall progress to reduce the negative side effects is inadequate for the desired transformation toward sustainable agriculture in poor countries. Globally, there have been no fundamental reflections about the role and functioning of mineral fertilisers over the past 5 decades or more, and compared to other sectors, dismal investments have been made in mineral fertiliser research and development (R\&D).
\end{abstract}

Prem S. Bindraban and Christian Dimkpa contributed equally to this work.

Prem S. Bindraban

pbindraban@vfrc.org

1 Virtual Fertilizer Research Center, Washington, DC, NW 20006, USA

2 International Fertilizer Development Center, Muscle Shoals, AL, USA

3 Wageningen University and Research Center, Wageningen, The Netherlands
In this paper, we reflect on current fertilisers and propose a more deliberate adoption of knowledge of plant physiological processes - including the diversity of mineral nutrient uptake mechanisms, their translocation and metabolism - as an entry point in identifying the physicochemical "packaging" of nutrients, their composition, amount and timing of application to meet plant physiological needs for improved instantaneous uptake. In addition to delivery through the root, we suggest that efforts be redoubled with several other uptake avenues, which as of now are at best haphazard, for the delivery of nutrients to the plant, including above ground parts and seed coating. Furthermore, ecological processes, including nutrient-specific interactions in plant and soil, plantmicroorganism symbiosis, and nanotechnology, have to be exploited to enhance nutrient uptake. It is hoped that concerted $\mathrm{R} \& \mathrm{D}$ efforts will be pursued to achieve these strategies.

Keywords Agroecology and crop-specific fertilisers · Crop nutrition · Nanotechnology $\cdot$ Nutrient delivery strategies · Paradigm shift $\cdot$ Sustainable food security

\section{Introduction}

The use of mineral fertilisers is among key factors driving the increased global agricultural production required to feed the rising human population. Synthetic N compounds produce roughly half of today's world food (Erisman et al. 2008). Depending on food demand, improvements in nutrient uptake efficiency, production of biofuels and efficiency of nutrient recycling (Heffer and Prud'homme 2008; Cordell et al. 2009), the projected consumption of $\mathrm{N}$ fertilisers is likely to change from the current $105 \mathrm{Mt}$ (million tonnes) in 2010 to $80-180 \mathrm{Mt}$ by 2050 . Similarly, the consumption of phosphate $\left(\mathrm{P}_{2} \mathrm{O}_{5}\right)$ could change from the current $40 \mathrm{Mt}$ to $35-70 \mathrm{Mt}$ 
(Sutton et al. 2013), while current potash $\left(\mathrm{K}_{2} \mathrm{O}\right)$ consumption, approximating $29 \mathrm{Mt}$, may increase by 1 to $2 \%$ per annum, reaching about $32 \mathrm{Mt}$ in 2015 (FAO 2011; Zörb et al. 2014).

The global use of fertilisers is highly unbalanced: Overfertilisation in North America, Western Europe, China and India causes environmental pollution, while underutilisation in Africa, Eurasia and parts of Latin America causes soil mining (National Geographic 2013). It has been estimated that the over-fertilisation with $\mathrm{N}$ in China, occurring in the order of 11.8 Mt, could potentially double yields if used on the 174 million ha of cropland in sub-Saharan Africa (Ju et al. 2009; Twomlow et al. 2010). In addition, there is often an imbalance in the ratio of nutrients. In Africa, $\mathrm{N}$ and $\mathrm{P}$ consumption is estimated at $2.8 \mathrm{Mt}$ and $96 \mathrm{Kt}$, signifying increases of 150 and $16 \%$, respectively, between 1975 and 2005 (Peñuelas et al. 2012, 2013). This contrasts from the industrialised countries where both $\mathrm{N}$ and $\mathrm{P}$ supplies are balanced, or where soil $\mathrm{P}$ capital has been built up over time to offset any under supply (van der Velde et al. 2014; Withers et al. 2014). With secondary and micro-nutrients, use in crop production is virtually lacking in Africa (see for e.g. Vanlauwe et al. 2014). The application only of NPK for decades may have induced micronutrient deficiency and soil deterioration (Stoorvogel et al. 1993; Bindraban et al. 2012), with yield responses of between 20 and $70 \%$ increases found upon application of secondary and micronutrients, dependent on the crop (Zingore et al. 2008; Vanlauwe et al. 2014; Voortman and Bindraban 2015).

Currently, emphasis is placed on improving the use efficiency of fertilisers through the $4 \mathrm{R}$ Nutrient Stewardship principle, i.e. the use of fertiliser from the right source, at the right rate and at the right time, with the right placement (IPNI 2014). A range of agronomic practices are pursued to implement the 4R approach, including precision application, deep placement, row application, coating of fertilisers for slow release to reduce nutrient losses and tuning the timing and availability of nutrients to plant (Chien et al. 2009; Linquist et al. 2013). Unfortunately, the overall progress achieved through these practices has been insufficient to address the flaws of current fertilisers. Yet, fertiliser research has largely been neglected for several decades. Fuglie et al. (2011) estimated that the fertiliser industry invests only $0.1-0.2 \%$ of its revenue in $\mathrm{R} \& \mathrm{D}$, compared with about 10 and $15-20 \%$ by the seed and pharmaceutical sectors, respectively. Therefore, given the essentiality of fertilisers to secure sufficient food, there is an urgent need for revisiting the concept of fertilisers, to reduce its environmental footprint while making them more economically efficient for resource-poor farmers.

In achieving the aim of fertilisers, the desire is that the nutrients end up only in the target plant. In reality, however, nutrients in fertilisers do not all end up in the plant; up to 20 $80 \%$ of nutrients in fertilisers may be lost to the environment or temporarily accumulate in the soil due to several complex soil chemistries that preclude their immediate availability to the plant. This is truer for $\mathrm{P}$ and micronutrients than it is for $\mathrm{N}$ (Sebilo et al. 2013). There is, therefore, no doubt that producing fertilisers with better plant uptake potential would reduce nutrient loss, in turn reducing the amount of fertilisation required in the first place. Accordingly, Withers et al. (2014) made the case for perceiving fertilisers as an ingredient for feeding crops, rather than soil.

In this paper, we share our broad vision for a new path in fertiliser production and/or delivery strategies, especially in the context of developing countries, particularly of SubSaharan Africa. We propound that basic biological and ecological processes be taken as a starting point to create avenues for arriving at innovative fertilisers and plant nutrient delivery strategies. Subsequently, we discuss a number of considerations that could guide the production of novel fertilisers and alternative - and even complimentary-mechanisms to more efficiently deliver the nutrients into plants, thereby increasing fertiliser use efficiency.

\section{An overview for revisiting fertilisers}

\section{Nutrient-nutrient interactions}

In this section, we revisit basic aspects of nutrients and their interactions with crop and edaphic factors, to set the foundation for arriving at novel fertilisers. For their normal growth, plants require 14 nutrient elements in different amounts (Table 1). Other mineral elements, though not essential for plant growth, but which could be beneficial, include cobalt, selenium, silicon and sodium. Table 1 also presents the amounts of each of the essential nutrients required for growth for a generic plant, as well as their levels in one ton of crop seed, using maize kernel as an example. The table further presents the currently known chemical forms and mechanisms by which the nutrients are taken up by plants, factors that influence their bioavailability such as $\mathrm{pH}$ (Lucas and Davis 1961), and their uptake interaction with other nutrients (Marschner 2012). Given the similarity in the uptake forms (e.g. as ions) of some elements, it is vital to understand the antagonistic and synergistic interactions that may occur during uptake from the soil. This is important for producing fertilisers with specific compositions that are efficient for crop production. Antagonism occurs among most nutrients but appears to have been more examined among the micronutrients. Collectively, the uptake by plants of nutrient elements is directed by multiple transporters, many of which transport more than one nutrient type. For example, although the ironregulated transporter (Irt) is induced primarily by Fe deficiency, it transports $\mathrm{Fe}, \mathrm{Mn}, \mathrm{Cu}, \mathrm{Zn}$ and possibly other divalent cations into the plant (Sinclair and Krämer 2012). Thus, the potential of sharing similar uptake and transport systems by these ions results in competition among them, leading to 
Table 1 Plant-essential mineral elements: interaction in soil, uptake forms and typical concentrations in plants

\begin{tabular}{|c|c|c|c|c|c|c|}
\hline \multicolumn{4}{|c|}{ Plants need 14 nutrient elements (in addition to $\mathrm{C}, \mathrm{H}, \mathrm{O}$ ): } & \multicolumn{3}{|c|}{ Animals and humans need 22 nutrient elements: } \\
\hline \multicolumn{4}{|c|}{$\mathrm{N}, \mathrm{P}, \mathrm{K}, \mathrm{Mg}, \mathrm{Ca}, \mathrm{S}, \mathrm{Fe}, \mathrm{Mn}, \mathrm{Zn}, \mathrm{Cu}, \mathrm{B}, \mathrm{Mo}, \mathrm{Cl}$ and $\mathrm{Ni}$} & \multicolumn{3}{|c|}{$\mathrm{N}, \mathrm{P}, \mathrm{K}, \mathrm{Mg}, \mathrm{Ca}, \mathrm{S}, \mathrm{Fe}, \mathrm{Mn}, \mathrm{Zn}, \mathrm{Cu}, \mathrm{Mo}, \mathrm{Cl}, \mathrm{Ni}, \mathrm{Co}, \mathrm{Na}, \mathrm{Se}, \mathrm{I}, \mathrm{Cr}, \mathrm{V}, \mathrm{Sn}, \mathrm{As}$ and $\mathrm{F}$} \\
\hline Element & $\begin{array}{l}\text { Plant conc. } \\
\quad \mathrm{mg} \mathrm{kg}^{-1}\end{array}$ & $\begin{array}{l}\text { In maize grain } \\
\mathrm{g} \mathrm{ton}^{-1}\end{array}$ & Plant uptake form & $\begin{array}{l}\text { Nutrient movement in soil and } \\
\text { uptake mechanism }\end{array}$ & $\begin{array}{l}\text { Some factors affecting } \\
\text { availability }^{\mathrm{a}}\end{array}$ & $\begin{array}{l}\text { Uptake interaction } \\
\text { with }^{\mathrm{a}}\end{array}$ \\
\hline Nitrogen $(\mathrm{N})$ & 15,000 & 23,400 & $\mathrm{NO}_{3}^{-}, \mathrm{NH}_{4}^{+}$ & $\begin{array}{l}\text { Low and high-affinity } \\
\text { transport proteins }\end{array}$ & $\begin{array}{l}\text { Antagonism between } \mathrm{N} \\
\text { forms; acidic } \mathrm{pH} \\
\text { alkaline } \mathrm{pH}\end{array}$ & $\begin{array}{l}\mathrm{Cl}\left(\text { for } \mathrm{NO}_{3}{ }^{-}\right)(\text {other } \\
\left.\text { cations for } \mathrm{NH}_{4}^{+}\right)\end{array}$ \\
\hline $\begin{array}{l}\text { Phosphorus } \\
\text { (P) }\end{array}$ & 2000 & 3700 & $\mathrm{H}_{2} \mathrm{PO}_{4}^{-}, \mathrm{HPO}_{4}^{2-}$ & $\begin{array}{l}\text { Diffusion (likely under non- } \\
\text { deficient conditions); } \\
\text { phosphate transport proteins } \\
\text { under deficient conditions } \\
\text { (low or high affinity) }\end{array}$ & $\begin{array}{l}\text { Metal oxides (e.g. Fe, } \mathrm{Al}) \\
\text { and clay minerals; acidic } \\
\text { pH, alkaline } \mathrm{pH}\end{array}$ & $\mathrm{Zn}$ \\
\hline $\begin{array}{l}\text { Potassium } \\
\quad(\mathrm{K})\end{array}$ & 10,000 & 12,600 & $\begin{array}{l}\text { Monovalent ion } \\
\left(\mathrm{K}^{+}\right)\end{array}$ & $\begin{array}{l}\text { Diffusion (under non-deficient } \\
\text { conditions); K+ transporters } \\
\text { under limiting conditions; } \\
\text { Proton pumps (ATPases) }\end{array}$ & $\begin{array}{l}\text { Clay minerals, organic } \\
\text { matter; acidic } \mathrm{pH}\end{array}$ & $\begin{array}{l}\mathrm{NH}_{4}^{+}, \mathrm{Na}^{2+} \mathrm{CuO} / \\
\mathrm{ZnO} \text { oxides } \\
\text { reduce } \mathrm{K} \text { uptake }\end{array}$ \\
\hline $\begin{array}{l}\text { Magnesium } \\
\quad(\mathrm{Mg})\end{array}$ & 2000 & 1400 & $\mathrm{Mg}^{2+}, \mathrm{MgO}$ & $\begin{array}{l}\text { Divalent metal transport } \\
\text { proteins }\end{array}$ & Acidic $\mathrm{pH}$, alkaline $\mathrm{pH}$ & $\mathrm{NH}_{4}^{+}, \mathrm{Mn}$ \\
\hline Calcium $(\mathrm{Ca})$ & 5000 & 100 & $\mathrm{Ca}^{2+}$ & $\begin{array}{l}\text { Divalent metal transport } \\
\text { proteins }\end{array}$ & Acidic $\mathrm{pH}$, alkaline $\mathrm{pH}$ & $\mathrm{NH}_{4}^{+}, \mathrm{Cu}, \mathrm{Zn}$ \\
\hline Sulphur (S) & 1000 & 1500 & $\mathrm{SO}_{4}{ }^{2-}$ & $\begin{array}{l}\text { Low and high-affinity } \\
\text { transport proteins }\end{array}$ & Acidic $\mathrm{pH}$ & \\
\hline Element & $\begin{array}{l}\text { Plant } \\
\text { conc. }{ }^{a} \mathrm{mg}- \\
\mathrm{kg}^{-1}\end{array}$ & $\begin{array}{l}\text { In maize grain } \\
\mathrm{g} \mathrm{ton}^{-1}\end{array}$ & Plant uptake form & $\begin{array}{l}\text { Nutrient movement in soil and } \\
\text { uptake mechanism }\end{array}$ & $\begin{array}{l}\text { Some factors affecting } \\
\text { availability }^{\mathrm{a}}\end{array}$ & $\begin{array}{l}\text { Uptake interaction } \\
\text { with: }^{\text {a }}\end{array}$ \\
\hline Iron $(\mathrm{Fe})$ & 100 & 175 & $\mathrm{Fe}^{2+}, \mathrm{FeO}$ & $\begin{array}{l}\text { Reduction and transport by } \\
\text { divalent cation transporter } \\
\text { for dicots and non-grass } \\
\text { monocots; chelation of } \\
\text { trivalent } \mathrm{Fe} \text { in grass } \\
\text { monocots }\end{array}$ & Alkaline $\mathrm{pH}$ & $\mathrm{Zn}, \mathrm{Cu}, \mathrm{Mg}$, \\
\hline $\begin{array}{l}\text { Manganese } \\
\quad(\mathrm{Mn})\end{array}$ & 50 & 8.2 & $\mathrm{Mn}^{2+}$ & Divalent cation transporter & Alkaline $\mathrm{pH}$, acid $\mathrm{pH}$ & $\mathrm{Zn}, \mathrm{Fe}, \mathrm{Mg}$ \\
\hline Zinc $(\mathrm{Zn})$ & 20 & 26.4 & $\mathrm{Zn}^{2+}$ & Divalent cation transporter & $\begin{array}{l}\text { Alkaline } \mathrm{pH}, \mathrm{OM} \text {, clay, } \\
\text { phosphate }\end{array}$ & $\begin{array}{l}\mathrm{N}(+), \mathrm{P}(-), \text { cations } \\
\quad\left(\text { e.g. } \mathrm{Ca}^{2+}\right), \mathrm{Fe}, \mathrm{Cu}\end{array}$ \\
\hline Copper $(\mathrm{Cu})$ & 6 & 4.2 & $\mathrm{CuO}, \mathrm{Cu}^{+}, \mathrm{Cu}^{2+}$ & Divalent cation transporter & $\begin{array}{l}\text { Cations }(\mathrm{K}, \mathrm{Ca}, \mathrm{Na}, \mathrm{Zn}) \text {; } \\
\quad \text { alkaline } \mathrm{pH}\end{array}$ & $\begin{array}{l}\left.\text { cations (e.g. } \mathrm{Ca}^{2+}\right) \\
\text { Fe }\end{array}$ \\
\hline Boron (B) & 20 & 4.9 & $\begin{array}{l}\text { Uncharged boric } \\
\text { acid }\left[\mathrm{B}(\mathrm{OH})_{3}\right]\end{array}$ & $\begin{array}{l}\text { Diffusion; channel transport; } \\
\text { high-affinity transport } \\
\text { proteins }\end{array}$ & Alkaline $\mathrm{pH}$ & $\mathrm{pH}, \mathrm{N}, \mathrm{Ca}$ \\
\hline $\begin{array}{l}\text { Molybdenum } \\
\text { (Mo) }\end{array}$ & 0.1 & 0.63 & $\begin{array}{l}\text { Molybdate } \\
\quad\left(\mathrm{MoO}_{4}{ }^{2-}\right)\end{array}$ & Potentially $\mathrm{S}$ transporters & $\begin{array}{l}\text { Fe or Al hydroxides in acid } \\
\text { soil }\end{array}$ & $\mathrm{Cu}, \mathrm{Al} / \mathrm{Fe}$ oxides \\
\hline Chloride $(\mathrm{Cl})$ & 100 & 475 & $\mathrm{Cl}^{-}$ & $\begin{array}{l}\text { Proton pumps (ATPases) in } \\
\text { cell membrane }\end{array}$ & Fe or Al hydroxides, clay & $\mathrm{NO}_{3}^{-}$ \\
\hline Nickel (Ni) & 0.1 & 0.5 & $\mathrm{Ni}^{2+}$ & $\begin{array}{l}\text { Probably divalent metal } \\
\text { transporters }\end{array}$ & $\mathrm{pH}$ & $\begin{array}{l}\text { Competing divalent } \\
\text { cations }\end{array}$ \\
\hline
\end{tabular}

From Marschner 2012. The data on maize kernel contents for nutrients other than Cl, Mo and Ni were averaged from a 3-year measurement from plants raised under conventional (pesticide, lime and NPK fertiliser applications) conditions (Warman and Havard 1998). $\mathrm{Cl}^{-}$and $\mathrm{Mo}^{-}$data were obtained from the International Fertiliser Society's World Fertilizer Use Manual, and Ni content was from an unidentified seed source (Kohiyama et al. 1992).

antagonism. For instance, $\mathrm{Zn}$ inhibited both the bioavailability in the rhizosphere and plant uptake of $\mathrm{Fe}$ and $\mathrm{Mn}$ by bean, while $\mathrm{Cu}$ also influenced $\mathrm{Zn}, \mathrm{Fe}, \mathrm{Mn}$ and $\mathrm{Ca}$ contents in shoot (Dimkpa et al. 2014, 2015). Similarly, Fe treatment reduced the uptake of $\mathrm{Mn}, \mathrm{Zn}$ and $\mathrm{Cu}$ in the xylem sap of barley (Alam et al. 2001), and even at the level of the biological transporter, addition of $\mathrm{Zn}$ to a Fe-deficient system stimulated the expression of an Irt gene to a greater extent than Fe deficiency alone
(Connolly et al. 2002). Notably, such antagonism is not limited to soil-root uptake pathways, given that a foliar application of $\mathrm{Fe}$ also diminished $\mathrm{Mn}, \mathrm{Zn}$ and $\mathrm{Cu}$ uptake in wheat (Ghasemi-Fasaei and Ronaghi 2008). Antagonism among nutrient elements often occurs when the ratio of elements are unbalanced. It seems plausible that transporters, when presented with a mixture of nutrients composed of ions that they transport, would preferentially transport more of the 
more abundant nutrient, inhibiting the uptake of the less abundant minerals as observed in Arabidopsis for Mn vs. $\mathrm{Fe}$, and in bean for $\mathrm{Zn}$ vs. Fe and Mn (Yang et al. 2008; Dimkpa et al. 2014).

Similar to antagonistic interactions among nutrient elements, synergism in nutrient uptake also has been demonstrated. Synergism between $\mathrm{P}$ and $\mathrm{Mn}$, as well as between $\mathrm{K}$ and $\mathrm{Mn}$, and $\mathrm{Mg}$ and $\mathrm{Ca}$, is observed in barley, with increasing $\mathrm{P}$ application (Matula 1992). Riedell (2010) reported the enhanced accumulation of $\mathrm{Ca}$ and $\mathrm{Mn}$ with $\mathrm{N}$-fertiliser application in maize, which for Mn occurred over the plant's life cycle, while $\mathrm{Ca}$ uptake was enhanced at tasselling. Likewise, the application of $\mathrm{NH}_{4}{ }^{+}-\mathrm{N}$ and $\mathrm{P}$ enhanced $\mathrm{Zn}$ and $\mathrm{Fe}$ uptake by maize in calcareous soil by mechanisms involving the alteration of root traits and acidification of the rhizosphere (Ma et al. 2014).

The occurrence of antagonism or synergism among nutrients demonstrates how fertiliser formulations of specific nutrient composition can influence the overall nutrition of plants. Therefore, these phenomena ought to be considered when nutrients are formulated into fertilisers, so that compatible nutrients can be leveraged, while antagonistic ones are excluded.

\section{Assessments and diagnostics}

In view of the potentially vast impact of fertilisers on food and the environment, Conijn et al. (2013) outlined a quantitative analytical framework to assess the impact of fertiliser interventions on the ecological drivers of planetary change aimed at raising societal awareness on the urgent need for fertiliser innovations. One approach in the 4R Nutrient Stewardship could be to synchronise the allocation of fertiliser types to soil types and weather conditions that could be identified with generic crop and soil modelling approaches. Systematic analyses of agro-ecosystems, with crop models as one tool, have allowed deeper understanding of the production ecological processes and functioning of these systems (Van Ittersum and Rabbinge 1997). De Wit (1992) showed that yields could reach 10 tons $\mathrm{ha}^{-1}$, well beyond mainstream insights, and revealed for instance that nutrients, rather than water, were limiting yields more severely in the Sahelian region. These findings have governed agricultural investments in developed nations, with current average wheat yield in the Netherlands of over 9.5 tons ha ${ }^{-1}$, up from about 3 tons $\mathrm{ha}^{-1}$ in the 1960s. Crop modelling is being used to identify fertiliser requirements to attain desired yield levels, but the poor resolution of soil data (Leenaars 2013; Hengl et al. 2014) and the complex interactions among the 14 plant nutrients (and other production factors) may allow identification of macro-nutrients requirements but not of secondary and micro-nutrients, whereas the latter nutrients are increasingly being demonstrated to be influential in crop yield in the unresponsive soils of Africa
(Vanlauwe et al. 2010, 2014 ). Complementing this approach with geo-spatial analysis based on soil testing and agronomic fertiliser trials would allow for analysing the direct relation between soil properties and the real effects of nutrients on yield, under given management practices. We recommend this integrated approach with initial research.

Soil and plant diagnostic tools, such as mobile spectrometers (Shepherd and Walsh 2007) and quick assessment kits, should become an integral part of fine-tuning fertiliser recommendations to soil type, and as guide to producers, traders and users, for targeting the most relevant fertiliser types to their regions and production systems. However, while many claims are made about new devices that rapidly measure soil properties, interpretation may appear cumbersome, as soil properties can be measured in different ways and the relevance of the data is likely to be crop-and environment-specific. This scenario calls for harmonisation and standardisation of data and methodologies. Also, instant methods for the assessment of nutrient contents of fertilisers are essential to prevent adulteration yet with daunting challenges (e.g. Perumal et al. 2014).

\section{Plant physiology and metabolic pathways}

We opine that the gap between the intended fertiliser functionality and their actual impact arises from the fact that fertilisers are made by chemists, chemical engineers and industrial processing technologists, following laws of physical and chemical processes, with little input from the knowledge of plant physiology and need for agro-ecological specificity of crop nutrition. A renewed impetus is, therefore, needed, to arrive at novel ways of packaging and delivering nutrients to plants, based on a better integration of the plant physiological and ecological processes related to the different modes of nutrient uptake, transport and metabolism. This should be harmonised with timing and quantities of nutrient required for the physiological growth processes, comparable to the packaging and administration of nutrients to humans, in sync with our metabolism.

Dependent on environmental conditions, crop specie, developmental stage and health status, plants differentially take up, transport, allocate and assign nutrients different organs. However, knowledge of the various uptake mechanisms and pathways, whether soil or aerially, has not been adequately harnessed to increase our understanding of the acquisition of nutrients by different food crops for the purpose of targeted and plant-specific fertiliser strategies. Here, we argue that a more unified knowledge of nutrient biochemical pathways in plants could help in targeting nutrient delivery to where most required and could facilitate further development of viable alternative uptake mechanisms such as foliar fertilisers (Voogt et al. 2013). In addition, understanding the ability of plants to increase their nutrient storage capacity could 
help to increase uptake, yield and food quality (Sinclair and Rufty 2012).

Uptake of nutrient elements as charged ions implies that active transport by proteins is required to move them across the root cell membrane. For example, $\mathrm{N}$ is taken up by plants in two metabolically dissimilar forms, $\mathrm{NO}_{3}{ }^{-}$or $\mathrm{NH}_{4}{ }^{+}$(Table 1; Masclaux-Daubresse et al. 2010). A portion of $\mathrm{NO}_{3}{ }^{-}$is transported to the leaves, where it is reduced to $\mathrm{NH}_{4}{ }^{+}$and then reacts with sugars to generate nucleic acids, amino acids and other building blocks, a rapid process necessary to avoid the risk of toxic ammonia production. In contrast, $\mathrm{NH}_{4}{ }^{+}$is metabolised mainly in the root, due, perhaps, to its lower mobility. Considering that sugars are produced in the leaves prior to root delivery, the form of $\mathrm{N}$ applied to crops could cause differential responses in the plant under different environmental conditions (Moritsugu et al. 1983). In hightemperature agro-ecological conditions, leaf sugar would be metabolised at a faster rate due to temperature-induced increase in respiration, resulting in less sugar being availed the root for conversion into derived products. Under such condition, $\mathrm{N}$-fertiliser primarily based on $\mathrm{NH}_{4}{ }^{+}$may not support plant growth to the desired extent. Accordingly, leafy vegetables may benefit more from $\mathrm{NO}_{3}{ }^{-} \mathrm{N}$ than $\mathrm{NH}_{4}{ }^{+} \mathrm{N}$ application, since the former would be transported to the leaves where the sugar is metabolised. On the other hand, at lower temperatures where sugars are more readily available to the root, coupled with reduced transport of $\mathrm{NO}_{3}{ }^{-}, \mathrm{NH}_{4}{ }^{+}$might be the preferred $\mathrm{N}$-fertiliser. Thus, dependent on environmental conditions, specific plant physiologies should be leveraged to target fertiliser types to crops.

As indicated, the role of micronutrients in influencing plant growth and yield, even in the presence of adequate NPK, is becoming increasingly obvious, and nowhere is this more apparent than in the nutrient-poor soils of many African countries (Vanlauwe et al. 2010, 2014). The uptake of some ionic micronutrients from the soil is preceded by their biological conversion to forms amenable for root uptake. With $\mathrm{Fe}$, for example, the conversion of $\mathrm{Fe}^{3+}$ to $\mathrm{Fe}^{2+}$ is accomplished by members of a dicot and non-grass monocot metal reductase enzyme family embedded in the root plasma membrane (Norvell et al. 1993; Robinson et al. 1999). In contrast, roots of grass monocots exude phytosiderophores into the rhizosphere to scavenge for $\mathrm{Fe}^{3+}$, wherein the intact $\mathrm{Fe}$ siderophore complex is taken up (Schaaf et al. 2004). Although both the reductase and phytosiderophore systems are induced in response to Fe deficiency, they are nonspecific enough to competitively permit the uptake of other mineral nutrients such as $\mathrm{Mn}, \mathrm{Zn}$ and $\mathrm{Cu}$ (Schaaf et al. 2004; Johnson and Barton 2007). Yet, current fertiliser formulations with micronutrients involve their amendment into the main NPK fertilisers, with little, if any, concern about the fate of competing micronutrients in the formulations. Given the role of micronutrients in crop yield and quality, the influence of specific plant-nutrient physiology on the use efficiency of micronutrient fertiliser formulations deserves not only continuous but also unified research. Furthermore, the role of specific plant root exudates (organic acids, phytosiderophores and reductants) in influencing nutrient availability to plants should be rigorously explored as a step not only towards crop-specific fertiliser production but also for integrated soil fertility management practices, such as selecting crop species for beneficial intercropping (Badri and Vivanco 2009; Zuo and Zhang 2009; Berendsen et al. 2012; Pii et al. 2015).

Obviously, a clearer understanding of the physiology surrounding plant nutrition should permit the identification of a range of nutrient delivery strategies that ensure both instantaneous plant uptake and administration of the relevant nutrient. As illustrated below (Fig. 1), in addition to soil applicationwhether broadcast, placed or timed-fertilisation strategies can be better integrated to include management of seed nutrient content, seed coating, soil, leaf and fruit application, and exploitable throughout the crop cycle. Figure 1 illustrates how the currently fragmented fertilisation regimes could be integrated into a comprehensive system that considers different and complementary fertilisation pathways. In such a system, field (soil) or seed-specific nutrient content determinations should direct subsequent application of fertilisers. Consequently, fertilisers for soil application or seed coating should be selected based on their content of nutrients that promote early germination and root growth (Smit et al. 2013). For nutrients involved in chlorophyll and/or photosynthetic processes, foliar application may be exploited to preclude uptake inhibitions caused by complex soil chemistry and the long-distance transport via root to shoot. In essence, nutrients should be applied to plant areas where they are most physiologically relevant.

\section{Soil-plant relations}

Soil properties dictate to a very large degree the responses of crops to nutrient elements. The $\mathrm{pH}$ of a soil, for example, can determine the extent to which a nutrient is available to plants (Marschner 2012). Change in $\mathrm{pH}$ induced by a fertiliser treatment could also complicate the situation: The alkaline nature of some urea-micronutrient mixed fertilisers could impede nutrient solubility and, therefore, availability, as observed for $\mathrm{Zn}$ amended to urea (Milani et al. 2012). $\mathrm{NH}_{4}{ }^{+}$-based fertilisers would acidify the soil due to proton release, thereby affecting $\mathrm{P}$ availability. However, $\mathrm{N}$-fertilisers that acidify the rhizosphere would be suitable for alkaline soils where $\mathrm{Fe}, \mathrm{Zn}$ and $\mathrm{Mn}$ availability are limited. Yet, in many production systems, different fertilisers are applied to soil without proper consideration of soil $\mathrm{pH}$, or the effects of the applied fertiliser on soil $\mathrm{pH}$ and thus the availability of other nutrients.

Fortunately, plants can adapt to soil properties in order to enhance their ability to dissolve and take up nutrients from the 
Fig. 1 Different fertilisation strategies applicable throughout the crop's life cycle

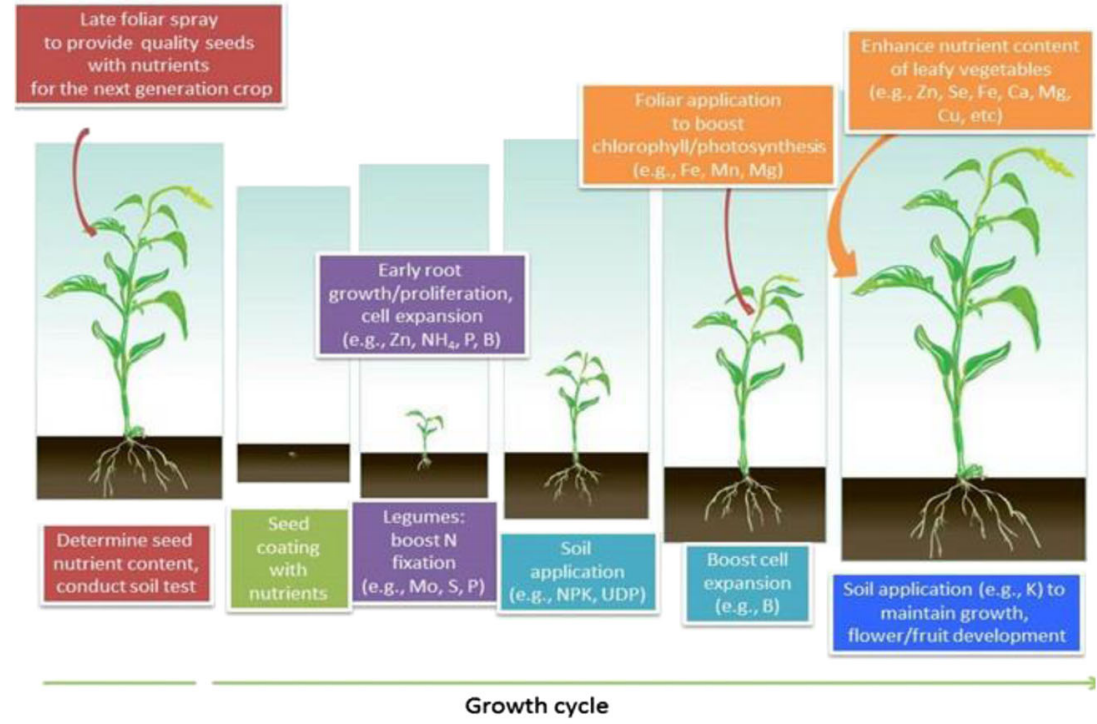

soil. These adaptations may feature anatomical, morphological or physiological characteristics in specific environments such as nutrient-poor soils (Aerts 1999). Morphologically, roots may develop high competitive ability for nutrient uptake through extensive rooting systems. Physiological responses such as a large internal nutrient pool, low nutrient content in plant tissue, enhanced remobilisation within plants and low rates of nutrient loss have been reported (e.g. Marschner 2012). Anatomical features in roots or leaves may assist in facilitating nutrient uptake and transport. Other plants have evolved to live in symbiosis with fungi and bacteria, or as indicated, excrete organic acids in order to increase soil nutrient uptake (Badri and Vivanco 2009; Hinsinger et al. 2009). Despite these potentials, knowledge about these mechanisms is fragmented, with varying claims about their effectiveness being found in laboratory and greenhouse experiments (e.g. Koele et al. 2014). The ultimate applicability under field conditions is less apparent.

Soils, whether poor or fertile, often contain more nutrients than required for crop annual uptake, but a proportion of the nutrients are chemically fixed in soil. For example, due to its strong reaction with soil and subsequent lack of mobility, especially in the acidic soils of the tropics and subtropics, $\mathrm{P}$ is limited in bioavailability in about $30-40 \%$ of the world's arable land (Runge-Metzger 1995; Sanchez et al. 1997). Extensive root systems such as longer roots, more lateral roots and more root hairs are essential to gain access to these nonbioavailable nutrients (Zhu and Lynch 2004; Hammond et al. 2009; Ma et al. 2013). Smit et al. (2013) discuss how enhancing early root growth could stimulate uptake of $\mathrm{P}$, as young roots have high uptake capacity. In addition to $\mathrm{P}$, changes in root architecture are induced by $\mathrm{NH}_{4}{ }^{+}, \mathrm{Zn}, \mathrm{K}$ and $\mathrm{Na}$ (the last two as chloride salts), leading to an enhanced ability to accumulate not only the nutrient in question but also others (Potters et al. 2007, and references therein; Ma et al. 2013; Stewart et al. 2015). Thus, the modification of root architecture by certain nutrient elements could have a profound influence on the overall plant nutritional status. This effect can be significant when these nutrients are applied in a way that boosts early changes in root architecture, thus stimulating early growth of the plants. Despite these opportunities, the lack of systematic research that directly link nutrient element-induced changes in root architecture to the overall enhancement of plant growth and nutrition with a view to designing crop-specific fertilisation strategies is remarkable.

\section{Trait identification}

Plant breeding, so far, has emphasised increase in yield potential, primarily of the major grains, by increasing the harvestable portion (Sayre et al. 1997), and has evolved to breeding for early maturity, resistance against pests and diseases, as well as tolerance to drought. However, despite all the information available on the diversity of nutrient uptake mechanisms, there has been only little focus on breeding for root architecture and nutrient uptake efficiency by roots. Even less attention has been paid to nutrient absorption from other plant organs and to the mechanisms involved in the absorption and metabolism of nutrients not supplied via the soil. Such novel and potentially more effective fertiliser delivery systems can be devised for agronomists and may entail the development of new plant varieties. Fortunately, some attention is now beginning to be paid to breeding for nutrient quality, such as increased Fe (Sperotto et al. 2012) and Zn (Mabesa et al. 2013) content. On the other hand, considering the stock of soil P (socalled legacy P) available in the intensive agricultural systems of Western Europe, North America and China, breeding crops that require less $\mathrm{P}$, without compromising crop performance, 
would be useful as well (see for e.g. Wang et al. 2010; Veneklaas et al. 2012). In this case, undesirable plant traits such as high phytate content could be managed by breeding plants with lower P requirements (Withers et al. 2014). Indeed, such breeding approach could address two issues: reducing the requirement for $\mathrm{P}$ fertiliser application and reducing, if not eliminating, the effect of phytate on the bioavailability of micro and secondary nutrients such as $\mathrm{Fe}, \mathrm{Zn}, \mathrm{Ca}$ and $\mathrm{Mg}$.

\section{Recycled fertilisers}

Once nutrients are taken up by plants and consumed by humans or animals, the waste ends up in the environment. Recycling of nutrients from waste water, manure and offal reduces overall losses and helps to recapture nutrients for plant uptake. Such organic fertilisers contain macro- and micro-nutrients, which may provide added value, compared with standard mineral fertilisers. Shahbaz et al. (2014) demonstrated that bioslurry not only helps to more than double the uptake of $\mathrm{N}$ in Okra at similar rates of $\mathrm{N}$-fertiliser application but also increases fruiting (number and weight) and dry matter content of plants. They associate this finding to favourable conditioning by the bioslurry of soil characteristics related to microbial activity that reduces $\mathrm{N}$ losses. These workers did not, however, discuss the role of the micronutrients contained in the bioslurry that also might have contributed to the increased $\mathrm{N}$ uptake (Oprica et al. 2014). In contrast, Islam (2006) reports only small yield effects of bioslurry amendment.

Despite the potential benefits, organic fertilisers may be unbalanced in terms of relative availability of nutrients, as well as having potentially harmful components such as bacteria, fungi or toxic levels of (micro) nutrients, heavy metals or toxic organic compounds. Fortunately, protocols are being developed to ensure the usefulness of organic fertilisers (Mukome et al. 2013; Oprica et al. 2014), and for testing of fractioning methods for obtaining correct information regarding nutrients in different forms of organic waste, including composts, slurries, sludges and digestates, such as for $\mathrm{P}$ and its solubility in the presence of other micronutrients (GarciaAlbacete et al. 2012). Along these lines, Withers et al. (2014) made a compelling case for increasing the use of recycled $\mathrm{P}$ from organic streams in order to substitute for freshly mined $\mathrm{P}$. Still, there is no doubt that proper processing and sound experimentation to disentangle the many nutrient variables affecting plant growth are essential for demonstrating the value of organic fertilisers. It would seem that given the many components in an organic fertiliser source, an assessment of the impact of recycled fertilisers on plant growth may fall short in terms of sound demonstration of the precise factor contributing to the crop performance. Often, the control treatments constitute no added nutrients or incomparable treatments of NPK lacking micronutrients (e.g. Jha et al. 2011).
Normative research that set standards and protocols for scientific scrutiny and evaluations of any fertiliser product, whether recycled or newly mined or manufactured, ought to guide the current, mostly unregulated entry of fertiliser products into the marketplace. The research should also allow the unravelling of the functioning mechanisms of the products, as the complexity of plant nutrient uptake processes may cause unpredictable product behaviour and cause them to be effective only under specific crop and environmental conditions.

\section{Novel fertilisers: tuning fertilisers and fertiliser technologies to farm practices}

Leveraging knowledge gained from the many different individual studies, the opportunity arises for the tuning of fertiliser technologies to better synchronise them with the understanding of plant nutrition and rhizosphere processes and be specific to crops and agro-ecosystems. This will contrast with the current practice of largely using generic fertilisers for most crops and soils. In the following sections, we highlight, based on evidence from the scientific literature, a number of interventions that could facilitate the attainment of a more comprehensive and effective crop fertilisation program.

\section{Seed nutrient content and seed coating with nutrients}

Guaranteeing good crop performance begins with the selection of quality seeds. In particular, the nutrient contents of a seed may be crucial to the performance of the ensuing plant when soil nutrients are in limited supply. Brodrick et al. (1995) emphasised the need for conducting nutrient analysis of seed batches prior to sowing. They show that Mo was a limiting factor in $\mathrm{N}_{2}$ fixation in soils in Eastern and Southern Africa and that sowing bean seeds with sufficient Mo contents in soil with low Mo prevents the production of Mo-deficient seeds until the fourth growth cycle. Therefore, the question arises whether a role in plant performance of nutrients carried over in seeds could be facilitated by spraying maturing fruits or seeds with specific nutrients prior to harvest to help boost the nutrient content for the next growth cycle (Fig. 1). Indeed, there is evidence that certain nutrients might be required to facilitate seed germination. In a 5-day germination study with rapeseed, seeds with low $\mathrm{S}, \mathrm{Mg}$ and $\mathrm{Ca}$ had germination failure, while seeds which took more than 3 days to germinate were Bdeficient (Eggert and von Wirén 2013). The finding for S, for example, is hardly surprising, it being a component of the early-required amino acids, cysteine and methionine, involved in antioxidant regulation and synthesis of hormones, DNA and proteins (Rajjou et al. 2012). Similarly, P has been well recognised in many studies as being required for seed germination and early development of seedlings (e.g. Catusse et al. 2008; Nadeem et al. 2011). Thus, determining seed nutrient contents in relation to seed germination and early 
seedling head-start for different crops could improve future crop productivity.

Following harvest and determination of seed nutrient contents, seeds can be coated with specific nutrients occurring in insufficient amounts in the seed, prior to next sowing (Fig. 1). In principle, coating seeds with nutrients permits the emerging radicle to make early contact with nutrients being released from the coating formulation onto the seed surface. While further systematic research would be necessary in this area, there is a strong prospect for coating of seeds with 'germination-boosting' nutrients to provide the impetus needed to establish early plant vigour as demonstrated in a few studies. For example, Nijënstein (2007) show that coating rye grass seeds with nutrients increased lateral root formation within the first 15 days of sowing, compared to plants from uncoated seeds. In that study, seed coating with $\mathrm{N}$ alone demonstrated greater efficacy than when combined with $\mathrm{P}$, although coating with $\mathrm{P}$ enhanced P uptake by the plant. Similarly, Wiatrak (2013) demonstrated for wheat that seed coating with a mixed formulation of $\mathrm{Cu}, \mathrm{Zn}$ and $\mathrm{Mn}$ (at 65,395 and $530 \mathrm{ml} \mathrm{kg}^{-1}$ seed) significantly increased plant biomass and grain yield, as well as plant $\mathrm{N}$ and $\mathrm{P}$ contents. However, no effect of the seed coating treatment was observed in $\mathrm{Cu}, \mathrm{Mn}$ and $\mathrm{Zn}$ contents. At higher (395 and $530 \mathrm{mg} \mathrm{kg}^{-1}$ seed) nutrient concentrations, coating of the seed also resulted in reduced $\mathrm{N}, \mathrm{P}$ and $\mathrm{Cu}$ uptake. Contrary to these findings, Scott et al. (1987) report that the emergence of wheat, but not oat, was reduced by $\mathrm{P}$ coating, whereas coating with urea reduced the emergence of both plants, more so, of wheat. Similarly, barley seeds coated with $\mathrm{P}$ had delayed germination but increased chlorophyll content and seed formation (Zeļonka et al. 2005). Collectively, these contrasting, even if haphazard, data suggest that the nutrient specificity of seed coating formulations and the initial nutrient content of seed lots need to be determined for different crops and that more systematic studies are required, prior to any deliberate widespread adoption of a fertiliser regime in which seed coating is a component.

\section{Foliar fertilisers}

It is known that nutrient-limiting processes such as antagonism among nutrients, extreme $\mathrm{pH}$ and other complex chemistries occur mainly in the soil, although there is evidence that antagonism between nutrients also could occur in planta (e.g. Ghasemi-Fasaei and Ronaghi 2008). However, circumventing the soil by applying nutrients through aerial plant parts can be a complementary fertilisation strategy, with the potential to address the restricted availability through the root. No doubt, uptake of nutrients applied from the shoot could be affected by surface tension of the suspension or solution, leaf cuticular morphology, age of leaf and environmental vagaries associated with the operations of the stomata (Fernández and Ebert 2005). Ideally, nutrient elements involved in shootspecific processes, such as $\mathrm{Mg}, \mathrm{Mn}$ and $\mathrm{Fe}$ in chlorophyll biosynthesis and photosynthesis, would be good nutrient candidates for foliar fertilisation (Fig. 1). As reviewed by Fenández and Ebert (2005), foliar application of Fe fertilisers is being used to mitigate chlorosis in crop plants. In addition, foliar application could increase the seed content of the nutrient, ultimately enhancing crop nutritional quality (Wang et al. 2012a, b). Foliar fertilisation may directly affect the yield and quality of leafy vegetables, yet this pathway may be less effective in cereals if foliar-applied nutrients are less mobile and thus more assimilated in leaf tissues, rather than being translocated to the grains. Whereas much is known about foliar application with $\mathrm{Fe}$, the wide-scale application of other nutrients and full integration of foliar strategies into current farming practices would require more in-depth research to (i) obtain reliable and reproducible application regimes, (ii) ascertain the feasibility of integration with pesticide and herbicide applications and (iii) determine crop responses specific to each nutrient and their combinations thereof.

An additional benefit of foliar application may be achieved by exploiting synergistic effects. In a comprehensive pot experiment with two controls, without and with basal NPK application, Oprica et al. (2014) showed that foliar application of a mix of $\mathrm{N}, \mathrm{P}, \mathrm{K}, \mathrm{Fe}, \mathrm{Cu}$ and $\mathrm{Mn}$ enhanced nutrient content in leaves and seeds of maize and sunflower, while increasing yield by $50 \%$ over the basal application of NPK alone. It is likely that the availability of micronutrients in the foliar fertiliser formulation may also have stimulated the uptake efficiency of the soil-applied NPK and, to our knowledge, is currently a subject of investigation at the AfricaRice Center.

\section{Beneficial micro-organisms as crop inoculants}

Besides the well-documented role of $\mathrm{N}$-fixation by symbiotic (e.g. Rhizobia) and free-living (e.g. Azotobacter and Azospirillum spp.) diazotrophs, soil microbes contribute to the nutrition of plants through various other processes. Bacillus subtilis can acidify the root environment, potentially helping to increase the solubility of fixed nutrients (Zhang et al. 2009). Pseudomonads streptomycetes and Bacilli serve as bio-fertilisers, producing phytohormones, siderophores and other growth-inducing compounds (Bulgarelli et al. 2013). Yet, other soil microbes function as biological control agents that negate the effects of pathogenic organisms, improving plant fitness, including fitness for nutrient assimilation and resistance to diseases, drought and metal toxicity (Koele et al. 2014). For example, Prasanna et al. (2013) found that inoculating tomato with the biocontrol cyanobacterium, Anabaena variabilis, when the plants are exposed to the plant pathogen Fusarium oxysporium resulted in increased plant growth, yield, shoot $\mathrm{P}$ and $\mathrm{Zn}$ contents, and correlated with 
increased activity of pathogen defence enzymes and, ultimately, to reduced mortality of the plants. Therefore, maintaining a diverse population of rhizosphere microorganisms by adequate management may be beneficial in the long run. The strong and multiple interactions imply, however, that the beneficial processes could be highly specific regarding plant species, soil, micro-organism and nutrients.

It is estimated that less than $5 \%$ of the soil $\mathrm{P}$ is readily available to plants (Bulgarelli et al. 2013). In this regard, a role for bacteria, mainly of the Bacillus, Pseudomonas and Penicillium genera, as well as arbuscular mycorrhizal fungi (AMF) in nutrient acquisition is further demonstrated in their ability to solubilise $\mathrm{P}$ mainly from tricalcium phosphate (TCP). Phosphate solubilising microbes (PSMs) perform their role by exuding organic acids such as citrate, acetate, succinate and gluconate, as well as by the enzymatic activities of phosphatases and phytases (Richardson and Simpson 2011; Bulgarelli et al. 2013; Koele et al. 2014). Thus, within the limits allowed by the complexity of soil chemistry and/or resident soil microbial interactions, microbial formulations, or preparations of organic acids that they produce, could be used as soil amendments specifically in soils with low P availability. Such formulations could contribute in the recycling of $\mathrm{P}$ fixed in soil from fertiliser treatments, thus reducing the entry of new P into the fertiliser system. Moreover, as P has been shown to increase the proliferation of root hairs, the effect on root density in turn could contribute in the better mining and uptake of other nutrients. In this regard, AMF, as part of the root system, are more extensive in nature and could explore spaces not reached by roots to exploit $\mathrm{P}$ for plant use. There has been a call to more accurately identify true PSMs based on their ability to solubilise $P$ from several, instead of single (TCP), P-metal complexes (Bashan et al. 2013a). Indeed, identifying true PSMs with the most promising agronomic potentials is vital, considering the increasing depletion of quality global phosphate reserves and competition for rock phosphate by non-agro industries, both leading to a skyrocketing of the prize of $\mathrm{P}$ fertilisers (Bashan et al. 2013b).

In contrast to rhizosphere microbes, the potential involvement of phyllosphere (shoot surface-dwelling) or endophytic bacteria in plant nutrient acquisition is not well resolved. Nonetheless, certain phyllospheric microbes could play a role in crop nutrition. For instance, the cynobacteria (Scytonema javanicum and Scytonema hofmanni; Freiberg 1998) impact $\mathrm{N}$ cycle by their ability to fix $\mathrm{N}$ or convert $\mathrm{NH}_{3}$ to $\mathrm{NH}_{4}{ }^{+}$on leaf surfaces (Freiberg 1998; Papen et al. 2002). Likewise, endophytes could contribute to plant nutrition of other minerals. For example Bacillus sp. B55 enhances S content and growth in tobacco seedlings under S-deficient conditions (Meldau et al. 2013). Notably, not only does this bacterium reduce organic S, but it also exudes the volatile, plant-assimilable $\mathrm{S}$ compound, dimethyl disulfide (DMDS). Therefore, for practical application, considering that DMDS is an organic, and thus biodegradable, compound, the question arises as to whether compound such as DMDS, or the bacteria producing them, could form a component of $\mathrm{S}$ nutrition in fertiliser formulations for S-deficient soils.

Opportunities, therefore, exist to systematically deploy specific plant-beneficial microbes as part of an integrated crop fertilisation management strategy. Indeed, different microbial inoculants are currently being commercially formulated for use in plant growth. Presently, an inventory of these formulations is being made and is the subject of an upcoming paper. There are indications that some of these bioformulations could be integrated into chemical fertilisers, which could potentially reduce mineral nutrient inputs (Greg O'Reilly, [Industry Stakeholder] personal communication). Nevertheless, the beneficial impact of currently available bioinoculants seems to vary greatly due to the complexity of the interactions, as well as potential issues with the stability of the inoculants over time, and under different climatic conditions. Moreover, many of the commercially available products may lack rigorous scientific evidence explaining their impact, warranting continued systematic research to clarify these controversies.

\section{Nanotechnology in fertilisers}

Nanotechnology is an emerging field with a strong promise to affect the current status of fertilisers. As such, this topic has been explored in some detail in this review. Nanomaterials having sizes in the $1-100-\mathrm{nm}$ range are highly reactive due to their small size and large surface area, compared to bulk materials. In 2013, the Project on Emerging Nanotechnologies (http://www.nanotechproject.org) reported that as of March 2011, some 1300 products contain nanomaterials, with the industry projected to exceed $\$ 3$ trillion by 2020 (Roco et al. 2011). Thus, it is anticipated that before long, the fertiliser industry will fully join in the nanotechnology revolution. Indeed, available evidence indicates that the chemical and physical attributes of nanomaterials can be exploited to achieve useful benefits in crop fertilisation (DeRosa et al. 2010; Ghormade et al. 2010; Gogos et al. 2012). Recently, patents and products containing nanomaterials for crop nutrition and protection are increasing (e.g. Gogos et al. 2012; Servin et al. 2015).

Different kinds of nanomaterials, including those manufactured from elements not traditionally classified as nutrients (e.g. titanium, silicon, silver) and nanoforms of micronutrients such as $\mathrm{Zn}, \mathrm{Fe}$ and $\mathrm{Mn}$, have been demonstrated as being able to improve crop growth and/or content of these elements (Larue et al. 2012; Wang et al. 2013a, b, c; Siddique and Al-Whaibi 2014; Servin et al. 2015). Often, the positive effects of nanoparticles (NPs) on crop growth occur to a greater extent than with the equivalent dose of the same mineral nutrient presented in ionic (salt) form (Alidoust and Isoda 2013; Pradhan et al. 2013; Zhao et al. 2013; Kim 
et al. 2014), and when applied at the same concentration at relatively high doses, the concentration at which toxicity occurs is lower with ions than with NPs (Dimkpa et al. 2012a; Pradhan et al. 2013; Kim et al. 2014). The enhanced beneficial effects of NPs are due likely to the fact that unlike ionic fertilisers where a significant portion of the nutrients could be lost due to the formation of phosphate and carbonate precipitates or other soil factors, exposure to NPs is potentially controlled by the sustained but low release of the functional ions from the particles which serve as reservoirs of ions (Dimkpa et al. 2012b), with plant-adequate amounts then likely taken up to offset losses due to interaction of the released ions with soil factors. Moreover, ions from the immediately soluble salts are readily available to the roots and could rapidly reach undesirable doses, subject to interactions with soil factors.

In addition to solubilisation in the soil (Antisari et al. 2013), some NPs can accumulate inside the plant root and/or shoot tissues as intact particles (Gardea-Torresdey et al. 2014; Antisari et al. 2015). For example, $\mathrm{Cu}$ presented as $\mathrm{CuO}$ NPs was taken up by maize and wheat in the particulate form (Wang et al. 2012a, b; Dimkpa et al. 2012a, 2013). Similarly, the presence of $\mathrm{Fe}$ and Mn NPs also has been observed in plants exposed to particulate $\mathrm{Fe}$ oxide and $\mathrm{Mn}$ (Ghafariyan et al. 2013; Pradhan et al. 2013), as has been MgO NPs in roots when exposure was via foliar application (Wang et al. 2013a, b, c). Notably, the same crop could differentially absorb different nutrient elements provided to it in particulate form through the root, as observed in wheat for $\mathrm{CuO}$ vs. $\mathrm{ZnO}$ $\mathrm{NPs}$, where $\mathrm{Cu}$ existed in wheat shoot mainly as $\mathrm{CuO}$ particles and a lower amount of dissolved forms, and $\mathrm{Zn}$ as $\mathrm{Zn}$ phosphate (Dimkpa et al. 2012a, 2013). Apparently, the ZnO NPs are dissolving in the rhizosphere and are initially absorbed by the plant as $\mathrm{Zn}^{2+}$, prior to their complexation with organic phosphate or other organic molecules inside the plant (Dimkpa et al. 2013; Wang et al. 2013a, b, c). Given the possibility that particulate forms of mineral nutrients could be mobilised and remobilised via the xylem and phloem respectively (Wang et al. 2012a, b, 2013a, b, c), unravelling the mechanisms involved in the plant transport of nutrient elements in particulate forms and their conversion into plantusable forms in planta could provide a promising pathway for micronutrient delivery as NPs or the packaging of nutrients in general in nanoparticle encapsulations that are also capable of being taken up intact by plants (DeRosa et al. 2010; Gogos et al. 2012; Zhang et al. 2012).

A recent study (Liu and Lal 2014) demonstrated that synthetic nanohydroxyapatite $\left[\mathrm{Ca}_{5}\left(\mathrm{PO}_{4}\right)_{3} \mathrm{OH}\right]$ as a source of $\mathrm{P}$ supply modestly increased soybean growth, biomass and yield relative to regular triple super phosphate $\left[\mathrm{Ca}\left(\mathrm{H}_{2} \mathrm{PO}_{4}\right)_{2}\right]$ application. Thus, the development of 'nanofertilisers' could be a promising technology by which both macro- and micronutrients can be delivered in nanoparticulate forms so that they provide a continuous source of soluble ions as they dissolve in the rhizosphere or in planta after particle uptake. Similarly, current fertilisers can be packaged into forms that enhance their solubility and accessibility in the rhizosphere or in the plant tissue by encapsulating the nutrients in biodegradable nanopolymers that sense nutrient deficiency cues such as root exudate production or $\mathrm{pH}$, releasing their nutrient contents for plant uptake in sync with the plant's need. Beyond single nutrients, composite NPs of different but compatible nutrients also can be delivered into plant tissues via soil or foliar application, where they slowly dissolve to release ions for plant assimilation, triggered by specific environmental signals. These applications would require an understanding of soil physicochemical properties as they relate to NP availability (see for e.g. Servin et al. 2015), which crops absorb which nutrients in which form, and whether there are dramatic differences in the amount of nutrients accumulated by crop plants from the different forms in which the nutrient elements could be presented to them.

Despite its immense benefits, nanotechnology also comes with risks because, similar to all chemical processes, it could have undesirable effects on non-target organisms, including plants and plant-associated soil microbes, depending on NP, dose applied and the biological species (Dimkpa et al. 2012b; Dimkpa 2014; Gardea-Torresdey et al. 2014). Accordingly, any large-scale adoption of nanotechnology for agricultural purposes must be supported by rigorous research to provide a better understanding of its agro-ecological ramifications, including the plant-specificity of the activity of the different nanomaterials, as well as any potential, dose-dependent, biotoxicity. Fortunately, such research endeavours are ongoing in many centres globally, funded by government agencies such as USDA, EPA and their EU and Asian equivalents, as indicated by funding agency disclosures in the published literature. The VFRC is presently starting to engage along these lines with agricultural nanoscientists (see for e.g. Servin et al. 2015).

\section{Towards transformation of fertilisers, fertilisation practices and the fertiliser sector}

No doubt, fertilisers have made, and will continue to make, notable contributions towards global provision of sufficient and nutritious food. However, due to under-use, fertilisers have not met the needs (increasing crop yield and quality and securing livelihoods) for which they are made, for many members of the global farming community in poor countries of Africa and some other regions. Increasing fertiliser use efficiency is the end result of the interplay among agrotechnological adjustment of the use of current fertilisers, ecological literacy, the socio-economic realities of farmers and an improved scientific knowledge base. In the latter case, the continuous, even if fragmented wealth of knowledge being 
gained from (i) edaphic and soil ecological processes such as interactions among nutrients, (ii) interaction between plants and microorganisms, and between nutrients and soil waterthat determine nutrient solubility and availability - (iii) alternative nutrient uptake forms (e.g. nano) and (iv) alternative routes of plant nutrients uptake and delivery can and should be leveraged to develop integrated fertiliser strategies that better address a plant's need.

A research protocol to tune nutrient delivery to plant's need, therefore, ought to include the following five considerations: crop, composition, packaging, application and ecosystem. More than ever before, a revisit of fertiliser research is needed to move from a mainly 'lifeless' physico-chemical process, to a 'living' biological process, whereby biologists, in an interactive process, work with chemists and chemical engineers in formulating and packaging the nutrients to meet specific crop metabolic requirements. Macronutrients may be sufficiently present in poor soils but not exploitable by crops because of limited root capacity, which could be increased through foliar application of micronutrients Thus, the array of packaging and delivery mechanisms could exploit synergistic processes while by-passing antagonism.

While some new strategies may entail adjustments of farm practices, fertiliser products could easily be integrated in current practices, while new approaches might even reduce input costs and increase farm produce and income. Fertigation, the delivery of nutrients through irrigation, is one such strategy that can be integrated into fertiliser regimes, tuned to appropriate application rates and crop demand, to potentially improving nutrient uptake efficiency (Yasuor et al. 2013). Foliar fertilisers of leaf-requiring nutrients could be provided along with current applications of other agro-chemicals. Fertilisers packaged in tablets, much like dishwasher tablets, would contain the right composition of micronutrients in right quantities for one application per knapsack for a specific crop and area, easing application practices. Nutrient-coating of seeds may not significantly alter existing farm practices. Labour requirements such as those for weeding may even be reduced up to $15-25 \%$, as is being observed with the deep placement of urea super granules at $7-10 \mathrm{~cm}$ below soil surface in rice, compared with broadcast application of prilled urea (IFDC 2014).

Recapturing of nutrients either directly lost from the field or after consumption by humans and animals has to become a much more integral part of fertiliser production. Recycling nutrient fertilisers should not only be encouraged because of the finite nature of mined nutrients but as an essential strategy for reducing the amount of new inert nutrients converted into reactive nutrients and released into the environment. Pursuing these different avenues to prompt the uptake of nutrients by crop plants and to recycle nutrients implies that increasing global food production may require the use of less, rather than more, mineral nutrients, globally (Withers et al. 2014).
However, mineral fertilisers use should still be increased in continents (e.g. Africa) that currently underutilise them.

A coherent revisiting of fertilisers and fertilisation strategies will set the stage for a new paradigm shift involving moving away from the current practice of largely using bulk generic fertilisers: 'large volume-low value, to low volume - high value' products. Clearly, transforming from bulk to targeted fertilisers calls for a transition by the fertiliser and related industry. Valuable lessons could be learned from developments in pesticides over the past decades that moved from toxic, persistent chemicals towards targeted, systemic bio-pesticides based on understanding of the relevant biological processes. In that case, research by the public and private sector, along with interventions by governments and concerns expressed by NGOs, all have contributed to the change, as was the involvement of actors in the production and distribution chain in multi-stakeholder platforms (Barzman and Dachbrodt-Saaydehb 2011). Change processes also may be catalysed by entrepreneurs, certainly if changing the course of the mainstream enterprises would require major industrial and business adjustments, including forward or backward integration. Finally, given the link between plant fertilisation/ nutrition and human nutrition, associated actors would include those from the health and medical sector, the chemical and food industry, and national and international development organisations.

Acknowledgments Funding for this work is provided by the United States Agency for International Development (USAID). Thanks to Susan Yiapan for help with manuscript editing.

Open Access This article is distributed under the terms of the Creative Commons Attribution 4.0 International License (http:// creativecommons.org/licenses/by/4.0/), which permits unrestricted use, distribution, and reproduction in any medium, provided you give appropriate credit to the original author(s) and the source, provide a link to the Creative Commons license, and indicate if changes were made.

\section{References}

Aerts R (1999) Interspecific competition in natural plant communities: mechanisms, trade-offs and plant-soil feedbacks. J Exp Bot 50:29-37

Alam S, Kamei S, Kawai S (2001) Effect of iron deficiency on the chemical composition of the xylem sap of barley. Soil Sci Plant Nutr 47: 643-649

Alidoust D, Isoda A (2013) Effect of gamma $\mathrm{Fe}_{2} \mathrm{O}_{3}$ nanoparticles on photosynthetic characteristic of soybean (Glycine max (L.) Merr.): foliar spray versus soil amendment. Acta Physiol Planta 35:33653375

Antisari LV, Carbone S, Gatti A, Vianello G, Nannipieri P (2013) Toxicity of metal oxide $\left(\mathrm{CeO}_{2}, \mathrm{Fe}_{3} \mathrm{O}_{4}, \mathrm{SnO}_{2}\right)$ engineered nanoparticles on soil microbial biomass and their distribution in soil. Soil Biol Biochem 60:87-94

Antisari LV, Carbone S, Gatti A, Vianello G, Nannipieri P (2015) Uptake and translocation of metals and nutrients in tomato grown in soil polluted with metal oxide $\left(\mathrm{CeO}_{2}, \mathrm{Fe}_{3} \mathrm{O}_{4}, \mathrm{SnO}_{2}, \mathrm{TiO}_{2}\right)$ or metallic 
(Ag, Co, Ni) engineered nanoparticles. Environ Sci Pollut Res 22: $1841-1853$

Badri DV, Vivanco JM (2009) Regulation and function of root exudates. Plant, Cell Environ 32:666-681

Barzman M, Dachbrodt-Saaydehb S (2011) Comparative analysis of pesticide action plans in five European countries. Pest Managt Sci 67: 1481-1485

Bashan Y, Kamnev A, de-Bashan LE (2013a) Tricalcium phosphate is inappropriate as a universal selection factor for isolating and testing phosphate-solubilizing bacteria that enhance plant growth: a proposal for an alternative procedure. Bio Fert Soils 49:465-479

Bashan Y, Kamnev A, de-Bashan LE (2013b) A proposal for isolating and testing phosphate-solubilizing bacteria that enhance plant growth. Bio Fert Soils 49:1-2

Berendsen RL, Pieterse CM, Bakker PA (2012) The rhizosphere microbiome and plant health. Trends Plant Sci 17:478-486

Bindraban PS, van der Velde M, Ye L, van den Berg M, Materechera S, Kiba DI, Tamene L, Ragnarsdottir KV, Jongschaap R, Hoogmoed M, Hoogmoed W, van Beek C, van Lynden G (2012) Assessing the impact of soil degradation on food production. Curr Opin Environ Sust 4:478-488

Brodrick SJ, Amijee F, KipeNolt JA, Giller KE (1995) Seed analysis as a means of identifying micronutrient deficiencies of Phaseolus vulgaris $\mathrm{L}$ in the tropics. Trop Agric 72:277-284

Bulgarelli D, Schlaeppi K, Spaepen S, van Ver Loren Themaat E, Schulze-Lefert P (2013) Structure and Functions of the Bacterial Microbiota of Plants. Ann Rev Plant Biol 64:807-838

Catusse J, Strub JM, Job C, Van Dorsselar A, Job D (2008) Proteomewide characterization of sugarbeet seed vigor and its tissue specific expression. Proc Natl Acad Sci U S A 105:10262-10267

Chien SH, Prochnow LI, Cantarella H (2009) Recent developments of fertilizer production and use to improve nutrient efficiency and minimize environmental impacts. Adv Agron 102:267-322

Conijn JC, de Ruijter FJ, Schröder JJ, Bindraban PS (2013) Methodology to assess the impact of fertilizer strategies on planetary boundaries. VFRC Report 2013/3 Virtual Fertilizer Research Center Washington, DC, pp 21

Connolly EL, Fett JP, Guerinot ML (2002) Expression of the IRT1 metal transporter is controlled by metals at the levels of transcript and protein accumulation. Plant Cell 14:1347-1357

Cordell D, Drangerta J, White S (2009) The story of phosphorus: global food security and food for thought. Glob Environ Chang 19:292305

DeRosa MC, Monreal C, Schnitzer M, Walsh R, Sultan Y (2010) Nanotechnology in fertilizers. Nature Nanotechnol 5:91-91

De Wit CT (1992) Resource use efficiency in agriculture. Agric Syst 40: $125-151$

Dimkpa CO (2014) Can nanotechnology deliver the promised benefits without negatively impacting soil microbial life? J Basic Microbiol 54:889-904

Dimkpa CO, McLean JE, Latta DE, Manangón E, Britt DW, Johnson WP, Boyanov MI, Anderson AJ (2012a) $\mathrm{CuO}$ and $\mathrm{ZnO}$ nanoparticles: phytotoxicity, metal speciation and induction of oxidative stress in sand-grown wheat. J Nanopart Res 14:1125

Dimkpa CO, McLean JE, Britt DW, Anderson AJ (2012b) Bioactivity and biomodification of $\mathrm{Ag} \mathrm{ZnO}$ and $\mathrm{CuO}$ nanoparticles with relevance to plant performance in agriculture. Industr Biotechnol 8:344 357

Dimkpa CO, Latta DE, McLean JE, Britt DW, Boyanov MI, Anderson AJ (2013) Fate of $\mathrm{CuO}$ and $\mathrm{ZnO}$ nano and micro particles in the plant environment. Environ Sci Technol 47:4734-4742

Dimkpa CO, Hansen T, Stewart J, McLean JE, Britt DW, Anderson AJ (2014) $\mathrm{ZnO}$ nanoparticles and root colonization by a beneficial pseudomonad influence essential metal responses in bean (Phaseolus vulgaris). Nanotoxicol DOI 10:3109/ 17435390.2014.900583
Dimkpa CO, McLean JE, Britt DW, Anderson AJ (2015) Nano-CuO and interaction with nano- $\mathrm{ZnO}$ or soil bacterium provide evidence for the interference of nanoparticles in metal nutrition of plants. Ecotoxicol 24:119-129

Eggert K, von Wirén N (2013) Dynamics and partitioning of the ionome in seeds and germinating seedlings of winter oilseed rape. Metallomics 5:1316

Erisman JW, Sutton MA, Galloway JN, Klimont Z, Winiwarter W (2008) How a century of ammonia synthesis changed the world. Nat Geosci $1: 636-639$

FAO (2011) Current world fertilizer trends and outlook to 2015. Rome

Fernández V, Ebert E (2005) Foliar iron fertilization: a critical review. J Plant Nutr 28:2113-2124

Freiberg E (1998) Microclimatic parameters influencing nitrogen fixation in the phyllosphere in a Costa Rican premontane rain forest. Oecologia (Berlin) 117:9-18

Fuglie KO, Heisey PW, King JL, Pray CE, Day-Rubenstein K, Schimmelpfennig D, Wang SL, Karmarkar-Deshmukh R (2011) Research investments and market structure in the food processing, agricultural input, and biofuel industries worldwide. ERR-130 US Dept of Agriculture Econ Res Serv December 2011

Garcia-Albacete M, Martin A, Cartagena CM (2012) Fractionation of phosphorus biowastes: characterisation and environmental risk. Waste Mgt 32:1061-1068

Gardea-Torresdey JL, Rico CM, White JC (2014) Trophic transfer, transformation, and impact of engineered nanomaterials in terrestrial environments. Environ Sci Technol 48:2526-2540

Ghafariyan MH, Malakouti MJ, Dadpour MR, Stroeve P, Mahmoudi M (2013) Effects of magnetite nanoparticles on soybean chlorophyll. Environ Sci Technol 47:10645-10652

Ghasemi-Fasaei R, Ronaghi A (2008) Interaction of iron with copper, zinc, and manganese in wheat as affected by iron and manganese in a calcareous soil. J Plant Nutr 31:839-848

Ghormade V, Deshpande MV, Paknikar KM (2010) Perspectives for nanobiotechnology enabled protection and nutrition of plants. Biotechnol Adv 29:792-803

Gogos A, Knauer K, Bucheli TD (2012) Nanomaterials in plant protection and fertilization: current state, foreseen applications, and research priorities. J Agric Food Chem 60:9781-9792

Hammond JP, Broadley MR, White PJ, King GJ, Bowen HC, Hayden R, Meacham MC, Mead A, Overs T, Spracklen WP, Greenwood DJ (2009) Shoot yield drives phosphorus use efficiency in Brassica oleracea and correlates with root architecture traits. J Exp Bot 60: 1953-1968

Heffer P, Prud'homme M (2008) Outlook for world fertilizer demand, supply, and supply/demand balance. Turkish J Agric Forest 32: 159-164

Hengl T, de Jesus JM, MacMillan RA, Batjes NH, Heuvelink GBM, Ribeiro E, Samuel-Rosa A, Kempen B, Leenaars JGB, Walsh MG, Gonzalez MR (2014) SoilGrids 1km-Global Soil Information Based on Automated Mapping. PLoS One 9, e105992. doi:10.1371/ journal.pone.0105992

Hinsinger P, Bengough AG, Vetterlein D, Young IM (2009) Rhizosphere: biophysics, biogeochemistry and ecological relevance. Plant Soil 321:117-152

IFDC (2014) http://www.ifdc.org/ (accessed September 2014)

IPNI (2014) http://www.nutrientstewardship.com/4r-news/newsletter/ ipni-issues-4r-plant-nutrition-manual. International Plant Nutrition Institute

Islam MS (2006) Use of bioslurry as organic fertilizer in Bangladesh agriculture. International Workshop on the Use of Bioslurry Domestic Biogas Programmes 27-28 Sept 2006 Bangkok Thailand

Jha P, Ram M, Khan MA, Kiran U, Mahmooduzzafara Abdin MZ (2011) Impact of organic manure and chemical fertilizers on artemisinin content and yield in Artemisia annua L. Industr Crops Prod 33: 296-301 
Johnson GV, Barton LL (2007) Inhibition of iron deficiency stress response in cucumber by rare earth elements. Plant Physiol Biochem 45:302-308

Ju XT, Xing GX, Chen XP, Zhang SL, Zhang LJ, Liu XJ et al (2009) Reducing environmental risk by improving $\mathrm{N}$ management in intensive Chinese agricultural systems. Proc Natl Acad Sci U S A 106: 3041-3046

Kim JH, Lee Y, Kim EJ, Gu S, Sohn EJ, Seo YS, An HJ, Chang YS (2014) Exposure of iron nanoparticles to Arabidopsis thaliana enhances root elongation by triggering cell wall loosening. Environ Sci Technol 48:3477-3485

Koele N, Kuyper TW, Bindraban PS (2014) Beneficial organisms for nutrient uptake. VFRC Report 2014/1. Virtual Fertilizer Research Center, Washington DC, p 63

Kohiyama M, Kanematsu H, Niiya I (1992) Heavy metals, particularly nickel content in oilseeds and edible vegetable oils. J Jpn Soc Food Sci Technol 39:439-445

Larue C, Laurette J, Herlin-Boime N, Khodja H, Fayard B, Flank AM, Brisset F, Carriere M (2012) Accumulation, translocation and impact of $\mathrm{TiO}_{2}$ nanoparticles in wheat (Triticum aestivum spp.): influence of diameter and crystal phase. Sci Total Environ 431:197-208

Leenaars JGB (2013) Africa Soil Profiles Database Version 1.1: a compilation of georeferenced and standardised legacy soil profile data for Sub-Saharan Africa (with dataset). ISRIC report 2013/03

Linquist BA, Liu L, Van Kessel C, van Groenigen KJ (2013) Enhanced efficiency nitrogen fertilisers for rice systems: metal-analysis of yield and nitrogen uptake. Field Crops Res 154:246-254

Liu R, Lal R (2014) Synthetic apatite nanoparticles as a phosphorus fertiliser for soybean (Glycine max). Sci Rep 4:5686

Lucas EE, Davis JF (1961) Relationships between $\mathrm{pH}$ values of organic soils and availability of 12 plant nutrients. Soil Sci 92:177-182

Ma Q, Zhang F, Rengel Z, Shen J (2013) Localized application of NH4+$\mathrm{N}$ plus $\mathrm{P}$ at the seedling and later growth stages enhances nutrient uptake and maize yield by inducing lateral root proliferation. Plant Soil 372:65-80

Ma Q, Wang X, Li H, Li H, Cheng L, Zhang F, Rengel Z, Shen J (2014) Localized application of $\mathrm{NH}^{+}-\mathrm{N}$ plus $\mathrm{P}$ enhances zinc and iron accumulation in maize via modifying root traits and rhizosphere processes. Field Crops Res 164:107-116

Mabesa RL, Impa SM, Grewal D, Johnson-Beebout SE (2013) Contrasting grain- $\mathrm{Zn}$ response of biofortification rice (Oryza sativa L.) breeding lines to foliar Zn application. Field Crops Res 149:223233

Marschner P (2012) Marschner's Mineral Nutrition of Higher Plants, 3rd edn. Elsevier Publishers, Oxford UK

Masclaux-Daubresse C, Daniel-Vedele F, Dechorgnat J, Chardon F, Gaufichon L, Suzuki A (2010) Nitrogen uptake, assimilation and remobilization in plants: challenges for sustainable and productive agriculture. Ann Bot 105:1141-1157

Matula J (1992) Interaction between potassium, magnesium, calcium, manganese and phosphorus in their uptake by barley. Rostlinna Vyroba 38:919-928

Meldau DG, Meldau S, Hoang LH, Underberg S, Wunsche H, Baldwin IT (2013) Dimethyl disulfide produced by the naturally associated bacterium Bacillus sp B55 promotes Nicotiana attenuata growth by enhancing sulfur nutrition. Plant Cell 25:2731-2747

Milani N, McLaughlin MJ, Stacey SP, Kirby JK, Hettiarachchi GM, Beak DG, Cornelis G (2012) Dissolution kinetics of macronutrient fertilizers coated with manufactured zinc oxide nanoparticles. J Agric Food Chem 60:3991-3998

Moritsugu M, Suzuki T, Kawasaki T (1983) Effect of nitrogen source on growth and mineral uptake in plants under constant $\mathrm{pH}$ and conventional culture conditions. Ber Ohara Inst Landw Biol Okayama Univ $18: 125-144$
Mukome FND, Doane TA, Silva LCR, Parikh J, Horwath WR (2013) Testing protocol ensures the authenticity of organic fertilizers. California Agric 67:210-216

Nadeem M, Mollier A, Morel C, Vives A, Pruud'homme L, Pellerin S (2011) Relative contribution of seed phosphorus reserves and exogenous phosphorus uptake to maize (Zea mays L) nutrition during early growth stages. Plant Soil 231-244

National Geographic (2013) http://ngm.nationalgeographic.com/2013/ 05/fertilized-world/nitrogen-flow-graphic

Nijënstein H (2007) Nutrient seed coating for grasses. http:// www.dlf.com/upload/etsc2008_iseed__nijenstein_-_final.pdf

Norvell WA, Welch RM, Adams ML, Kochain LV (1993) Reduction of $\mathrm{Fe}(\mathrm{III}), \mathrm{Mn}(\mathrm{III})$, and $\mathrm{Cu}(\mathrm{II})$ chelates by roots of pea (Pisum-sativum L) or soybean (Glycine max). Plant Soil 155:123-126

Oprica DI, Cioroianu TM, Lungu M, Badea IA (2014) A New ecofriendly foliar fertilizer with bone glue suitable for crops of maize and sunflower. Rev Chim 65:1-7

Papen H, Gessler A, Zumbusch E, Rennenberg H (2002) Chemolithoautotrophic nitrifiers in the phyllosphere of a spruce ecosystem receiving high atmospheric nitrogen input. Curr Microbiol 44:56-60

Peñuelas J, Sardans J, Rivas-ubach A, Janssens IA (2012) The humaninduced imbalance between C, N and P in Earth's life system. Glob Chang Biol 18:3-6

Peñuelas J, Poulter B, Sardans J, Ciais P, van der Velde M, Bopp L, Boucher O, Godderis Y, Hinsinger P, Llusa J, Nardin E, Vicca S, Obersteiner M, Janssens IA (2013) Human-induced nitrogen-phosphorus imbalances alter natural and managed ecosystems across the globe. Nat Comm 4:2934

Perumal K, Ananthi S, Arunkumar J, Sambanda Moorthy TA, Karthik B, Singh U, Bindraban PS (2014) Establishing a viable fertilizer quality detection system. VFRC Report 2014/4. Virtual Fertilizer Research Center, Washington DC, p 23

Pii Y, Mimmo T, Tomasi N, Terzano R, Cesco S, Crecchio C (2015) Microbial interactions in the rhizosphere: beneficial influences of plant growth-promoting rhizobacteria on nutrient acquisition process. A review. Biol Fert Foils 51:403-415

Potters G, Pasternak TP, Guisez Y, Palme KJ, Jansen MAK (2007) Stressinduced morphogenic responses: growing out of trouble? Trends Plant Sci 12:98-105

Pradhan S, Patra P, Das S, Chandra S, Mitra S, Dey KK, Akbar S, Palit P, Goswami A (2013) Photochemical modulation of biosafe manganese nanoparticles on Vigna radiata: a detailed molecular, biochemical, and biophysical study. Environ Sci Technol 47:13122-13131

Prasanna R, Chaudhary V, Gupta V, Babu S, Kumar A, Singh R, Shivay YS, Nain L (2013) Cyanobacteria mediated plant growth promotion and bioprotection against Fusarium wilt in tomato. Euro J Plant Pathol 136:337-353

Rajjou L, Duval M, Gallardo K, Catusse J, Bally J, Job C, Job D (2012) Seed germination and vigor. Annu Rev Plant Biol 63:507-533

Richardson AE, Simpson RJ (2011) Soil microorganisms mediating phosphorus availability. Plant Physiol 156:989-996

Riedell WE (2010) Mineral-nutrient synergism and dilution responses to nitrogen fertilizer in field-grown maize. J Plant Nutr Soil Sci 173: 869-874

Robinson NJ, Procter CM, Connolly EL, Guerinot ML (1999) A ferricchelate reductase for iron uptake from soils. Nature 39:694-697

Roco MC, Mirkin CA, Hersam MC (2011) Nanotechnology research directions for societal needs in 2020. Springer Science Policy Reports, New York

Runge-Metzger A (1995) Closing the cycle: obstacles to efficient P management for improved global food security. SCOPE 54 - phosphorus in the global environment - transfers, cycles and management

Sanchez PA, Buresh RJ, Leakey RRB (1997) Trees, soils, and food security. Phil Transac Royal Soc London Series B-Biol Sci 352:949960 
Sayre KD, Rajaram S, Fischer RA (1997) Yield potential progress in short bread wheats in northwest Mexico. Crop Sci 37:36-42

Schaaf G, Erenoglu BE, von Wiren N (2004) Physiological and biochemical characterization of metal-phytosiderophore transport in graminaceous species. Soil Sci Plant Nutri 50:989-995

Scott JM, Jessop RS, Steer RJ, Mclachlan GD (1987) Effect of nutrient seed coating on the emergence of wheat and oats. Fert Res 14:205217

Sebilo M, Mayer B, Nicolardot B, Pinay G, Mariotti A (2013) Long-term fate of nitrate fertilizer in agricultural soils. Proc Natl Acad Sci U S A 110:18185-18189

Servin A, Elmer W, Mukherjee A, De La Torre-Roche R, Hamdi H, White JC, Bindraban PS, Dimkpa CO (2015) A review of the use of engineered nanomaterials to suppress plant disease and enhance crop yield. J Nanopart Res 17:92

Shahbaz M, Akhtar MJ, Ahmed W, Wakeel A (2014) Integrated effect of different $\mathrm{N}$-fertilizer rates and bioslurry application on growth and N-use efficiency of okra (Hibiscus esculentus L) Turkish. J Agr Forest 38:311-319

Shepherd KD, Walsh MG (2007) Infrared spectroscopy - enabling an evidence-based diagnostic surveillance approach to agricultural and environmental management in developing countries. J Near Infrared Spectros 15:21-20

Siddique MH, Al-Whaibi MH (2014) Role of nano- $\mathrm{SiO}_{2}$ in germination of tomato (Lycopersicum esculentum seeds Mill). Saudi J Biol Sci 21:13-17

Sinclair SA, Krämer U (2012) The zinc homeostasis network of land plants. Biochim Biophys Acta 1823:1553-1567

Sinclair TR, Rufty TW (2012) Nitrogen and water resources commonly limit crop yield increases, not necessarily plant genetics. Glob Food Sec 1:94-98

Smit AL, Blom-Zandstra M, van der Werf A, Bindraban PS (2013) Enhancing early root growth to exploit indigenous soil $\mathrm{P}$ and fertilizer P. VFRC Report 2013/4. Virtual Fertilizer Research Center, Washington, DC, p pp 36

Sperotto RA, Ricachenevsky FK, de Abreu WV, Fett JP (2012) Iron biofortification in rice: it's a long way to the top. Plant Sci 190: 24-39

Stewart J, Hansen T, McLean JE, McManus P, Das S, Britt DW, Anderson AJ, Dimkpa CO (2015) Salts affect the interaction of $\mathrm{ZnO}$ or $\mathrm{CuO}$ nanoparticles with wheat. Environ Toxicol Chem. doi:10.1002/etc.3037

Stoorvogel JJ, Smaling EMA, Janssen BH (1993) Calculating soil nutrient balances in Africa at different scales: 1 Supra-national scale. Fert Res 35:227-235

Sutton MA, Bleeker A, Howard CM, Bekunda M, Grizzetti B, de Vries W et al (2013) Our nutrient world: the challenge to produce more food and energy with less pollution. Global Overview of Nutrient Management. Centre for Ecology and Hydrology Edinburgh, UK, on behalf of the Global Partnership on Nutrient Management and the International Nitrogen Initiative. http://www.initrogen.org/sites/default/files/documents/files/ONW.pdf

Twomlow S, Rohrbach D, Dimes J, Rusike J, Mupangwa W, Ncube B, Hove L, Moyo M, Mashingaidze N, Mahposa P (2010) Microdosing as a pathway to Africa's Green Revolution: evidence from broad-scale on-farm trials. Nutr Cycl Agroecosyst 88:3-15

Van der Velde M, Folberth C, Balkovic J, Ciais P, Fritz S, Janssens IA, Obersteiner M, See L, Skalsky R, Xiong W, Penuelas J (2014) African crop yield reductions due to increasingly unbalanced nitrogen and phosphorus consumption. Glob Chang Biol 20:1278-1288

van Ittersum MK, Rabbinge R (1997) Concepts in production ecology for analysis, quantification of agricultural input-output combinations. Field Crops Res 5:197-208

Vanlauwe B, Bationo A, Chianu J, Giller KE, Merckx R, Mokwunye U, Ohiokpehai O, Pypers P, Tabo R, Shepherd K, Smaling EMA, Woomer PL (2010) Integrated soil fertility management: operational definition and consequences for implementation and dissemination. Outlook Agric 39:17-24

Vanlauwe B, Descheemaeker K, Giller K, Huising J, Merckx R, Nziguheba G, Wendt J, Zingore S (2014) Integrated soil fertility management in Sub-Saharan Africa: unravelling local adaptation. Soil Discuss 1:1239-1286

Veneklaas EJ, Lambers H, Bragg J, Finnegan PM, Lovelock CE, Plaxton WC et al (2012) Opportunities for improving phosphorus-use efficiency in crop plants. New Phytol 195:306-320

Voogt W, Blok C, Eveleens B, Marcelis L, Bindraban PS (2013) Foliar fertilizer application - Preliminary review. VFRC Report 2013/2. Virtual Fertilizer Research Center, Washington DC, $\mathrm{p} 43$

Voortman R, Bindraban PS (2015) Beyond N and P: Toward a land resource ecology perspective and impactful fertilizer interventions in Sub-Saharan Africa. VFRC Report 2015/1. Virtual Fertilizer Research Center, Washington DC, p 49

Wang X, Shen J, Liao H (2010) Acquisition or utilization, which is more critical for enhancing phosphorus efficiency in modern crops? Plant Sci 179:302-306

Wang J, Mao H, Zhao H, Huang D, Wang Z (2012a) Different increases in maize and wheat grain zinc concentrations caused by soil and foliar applications of zinc in Loess Plateau China. Field Crops Res 135:89-96

Wang Z, Xie X, Zhao J, Liu X, Feng W, White JC, Xing B (2012b) Xylem- and phloem-based transport of $\mathrm{CuO}$ nanoparticles in maize (Zea mays L). Environ Sci Technol 46:4434-4441

Wang J, Koo Y, Alexander A, Yang Y, Westerhof S, Zhang QB, Schnoor JL, Colvin VL, Braam J, Alvarez PJJ (2013a) Phytostimulation of poplars and Arabidopsis exposed to silver nanoparticles and $\mathrm{Ag}^{+}$at sublethal concentrations. Environ Sci Technol 47:5442-5449

Wang P, Menzies NW, Lombi E, McKenna BA, Johannessen B, Glover CJ, Kappen P, Kopittke PM (2013b) Fate of ZnO nanoparticles in soils and Cowpea (Vigna unguiculata). Environ Sci Technol 47: $13822-13830$

Wang WN, Tarafdar JC, Biswas P (2013c) Nanoparticle synthesis and delivery by an aerosol route for watermelon plant foliar uptake. J Nanopart Res 15:1417

Warman PR, Havard KA (1998) Yield, vitamin and mineral contents of organically and conventionally grown potatoes and sweet corn. Agric Ecosys Environ 68:207-216

Wiatrak P (2013) Influence of seed coating with micronutrients on growth and yield of winter wheat in southeastern coastal plains. Ame J Agr Biol Sci 8:230-238

Withers PJA, Sylvester-Bradley R, Jones DL, Healey JR, Talboys PJ (2014) Feed the crop not the soil: rethinking phosphorus management in the food chain. Environ Sci Technol 48:6523-6530

Yang TJW, Perry PJ, Ciani S, Pandian S, Schmidt W (2008) Manganese deficiency alters the patterning and development of root hairs in Arabidopsis. J Exp Bot 59:3453-3464

Yasuor H, Ben-Gal A, Yermiyahu U (2013) Nitrogen management of greenhouse pepper production: agronomic, nutritional, and environmental implications. Hortsci 48:1241-1249

Zelionka L, Stramkale V, Vikmane M (2005) Effect and after-effect of barley seed coating with phosphorus on germination, photosynthetic pigments and grain yield. Acta Uni. Latv Biol 691:111-119

Zhang HM, Sun Y, Xie XT, Kim MS, Dowd SE, Pare PW (2009) A soil bacterium regulates plant acquisition of iron via deficiencyinducible mechanisms. Plant J 58:568-577

Zhang M, Ellis EA, Cisneros-Zevallos L, Akbulut M (2012) Uptake and translocation of polymeric nanoparticulate drug delivery systems into ryegrass. RSC Adv 2:9679-9686

Zhao L, Sun Y, Hernandez-Viezcas JA, Servin AD, Hong J, Niu GH, Peralta-Videa JR, Duarte-Gardea M, Gardea-Torresdey JL (2013) Influence of $\mathrm{CeO}_{2}$ and $\mathrm{ZnO}$ nanoparticles on cucumber 
physiological markers and bioaccumulation of $\mathrm{Ce}$ and $\mathrm{Zn}$ : a life cycle study. J Agric Food Chem 61:11945-11951

Zhu JM, Lynch JP (2004) The contribution of lateral rooting to phosphorus acquisition efficiency in maize (Zea mays) seedlings. Funct Plant Biol 31:949-958

Zingore S, Delve RJ, Nyamangara J, Giller KE (2008) Multiple benefits of manure: the key to maintenance of soil fertility and restoration of depleted sandy soils on African smallholder farms. Nut Cycl Agroecosyst 80:267-282

Zörb C, Senbayram M, Peiter E (2014) Potassium in agriculture - status and perspectives. J Plant Physiol 171:656-669

Zuo Y, Zhang F (2009) Iron and zinc biofortification strategies in dicot plants by intercropping with gramineous species: a review. Agron Sustain Dev 29:163-171 